\title{
Ethnopsychiatry and Theories of "the African Mind": A Historical and Comparative Study
}

Nicholas J. Carson ${ }^{*}, \underline{B . A .}$

* To whom correspondence should be addressed:

Faculty of Medicine, McGill University, 3655 Drummond St., Montreal, QC, Canada, H3G 1Y6

Ethnopsychiatry in colonial Africa was not simply a form of scientific inquiry and medical practice, but an application of colonial ideology. The development of ethnopsychiatry parallels the déroulement of European colonial involvement in Africa from the mid-nineteenth century to the 1960s (1). As an academic discipline, early ethnopsychiatry encompassed historical anthropology, psychiatry and sociology. The broad array of workers in colonial Africa who are currently regarded as pioneer "ethnopsychiatrists" were those men of predominantly European origin who sought theories to understand and treat African mental function and dysfunction. Upon examination, it becomes clear that their ethnopsychiatric theories stemmed from and supported contemporary social hypotheses concerning the psychology of the colonizer-colonized relationship.

A comparison of two researchers*Dr. John Colin Carothers and Dr. Frantz Fanon*who were active in the field of ethnopsychiatry during the early twentieth century, elucidates the evolution of thought concerning the socalled "African mind," and further illustrates how such theories were translated into medical practice in Kenya, Algeria, and other African countries.

The early ethnopsychiatrists in colonial Africa adopted an approach to their work which was similar to that of their anthropologist predecessors. In 1898,

on a British expedition to the Torres Islands in the South Pacific, five researchers trained in anthropology and psychology spent seven months observing and recording physical and mental traits of the area's natives including "sensitivity to light, vision, hearing, sensitivity to pain, memory, mental fatigue and muscular power" (1). The goal of the expedition was to investigate the commonly debated notion that non-Europeans were "insensate." Finding fuel, in the form of scientific data, for the "insensate debate" was the driving force behind the Torres expedition. Subsequent ethnopsychiatric work in Africa was strongly influenced by this preconceived notion that behavioral difference is proportional to physical difference. As part of the ideological background of colonialism, this belief affected the delivery of mental health care to Africans.

Carothers, whose work is representative of early ethnopsychiatric study in Africa, was the director of Nairobi's Mathari Mental Hospital from 1938 to 1950. He entered this lofty position with a background in neither psychology nor psychiatry, "consistent with the low priority given to mental health in the colony" (1). However, Carothers found his niche and soon became one of the foremost ethnopsychiatrists of his time. His major work, The African Mind in Health and Disease, was published in 1953, three years after his return to England. In this work, which met with wide acclaim, Carothers categorizes a number of African "races"*Bushman, Pygmy, Hottentot, Negro, Hamite and Semite*on the basis of head shape, quality of hair 
and facial features. He further attempts to correlate the brain sizes of subjects from these different African "races" with their individual levels of education (2). Thus, in keeping with the approach of the British anthropologists in the Torres Islands, Carothers upheld physical traits as "psychological indicators."

In searching for a plausible theory of African psychology, Carothers attempted to explain a perceived difference between Africans and Europeans. He notes gross variation in physical characteristics, such as skin color, which he then correlates with supposed differences in cognitive capability. He quotes Sequeira, the renowned dermatologist, in support:

both the cerebral cortex and the epidermis are derived from the same elementary embryonic layer--the epiblast....It should therefore not be surprising on embryological grounds to find differences in the characters of the cerebral cortex in different races (2).

Carothers also investigated the general shape, fissuration and cortical histology of the African brain as compared to the European brain. While he notes that "no sweeping conclusions in regard to African mentality can be arrived at on the basis of these data," his general conclusion was that Africans exhibit a "cortical sluggishness" due to under-use of the frontal lobes, which inhibited their ability to synthesize information (3).

With the frontal lobe hypothesis, Carothers claimed that cognitive or mental inferiority was an inherent state in the African. "With the Negro," he writes, "emotional, momentary and explosive thinking predominates ... dependence on excitement, on external influences and stimuli, is a characteristic sign of primitive mentality." According to Carothers, the African's "mental development is defined by the time he reaches adolescence, and little new remains to be said" (3). In this supposed child-like permanence, "above all, the importance of physical needs (nutrition, sexuality)" prevail (2). This belief was used as proof that Africans could not appreciate the Victorian moral values of hard work and education, the desire for which was said to have come in part through denial of the sexual drive. By extension, the African was denied the possibility of reaching a civilized state.

Carothers also claimed that the African exhibits an "impulsivity [that is] violent but unsustained, ... an 'immaturity' which prevents complexity and integration in the emotional life" (2). Using this discourse of violence, he medicalized "mental illness" as a normal physical state in the African. When the British administration in Kenya called upon Carothers to assess the Mau Mau rebellion (1945-1952), ethnopsychiatry was "commandeered to clothe the political interests of the colonists in the pseudo-scientific language of psychiatry to legitimize European suzerainty" (4). After due investigation, Carothers reported to the British government that "the onus for the rebellion rests with the deficiencies characteristic of the native Kenyans and not with the policies of the British colonial desire" (3).

Similarly, views derived from ethnopsychiatric research were translated into medical practice in the colonial asylums for the mentally ill. Stereotypes of African violence combined with economic scarcity contributed to the confinement of most "lunatics" living within general prison populations. Early early century case studies from the Zomba Lunatic Asylum in Nyasaland (now Malawi) illustrate the prevailing attitudes towards "madness," the place of mentally ill patients in colonial society, and the political and economic circumstances in which psychiatric care was given.

The Zomba Asylum was opened as part of Nyasaland's Central Prison in 1910, and housed "natives who [were] mentally deranged and [were] usually criminal or dangerous" until 1951. The Asylum was monitored by untrained guards. A firsthand description of patient/inmate reads as follows: "no attempt is made to treat and understand the patients. When a patient is noisy, violent or troublesome he is locked in a cell or put in irons" (5). Misdiagnosis was common, and so-called lunatics often suffered from physical illnesses including tertiary syphilis, epilepsy and brain injury (1). Many patients also suffered from the stress and conflict of colonial rule and were labeled deranged. 
According to Vaughan, who conducted an extensive study of the Nyasaland Asylum records from the colonial period:

Madness .... was made out of the occasional stammering attempts at direct communication between the two cultures [African and European] .... The real problem lay with those Africans whose 'brains had been turned by a little schooling', the idioms of whose madness were motor cars, bicycles, kings of England and silver mines; who flung back at the conquerors their own images of superiority in disturbingly distorted forms (5).

Thus, the colonial situation gave patients a set of symbols through which they expressed their ills. European psychiatrists of the era, in turn, responded to these expressions of "madness" with therapies designed to assimilate patients as colonial citizens.

The structural change which allowed the creation of a mental hospital in Zomba's Central Prison reveals the colonial ideology which directed mental health care in Africa. Core colonial concepts of "liberal ideology and the myth of colonialism as a civilizing mission" addressed the "madness" described above by requiring that Africans suffering from mental illness be given some form of care (1). In keeping with this mythical mission, wards of the Zomba asylum were made to perform physical labour and to attend Christian services. By the 1950s, electroconvulsive therapy (ECT) had made its way to Africa. The use of ECT on Africans was representative of British psychiatry's attempt to mould good citizens of the Empire out of patients who, ironically, presented their mental illnesses through this paradigm of colonial citizenship. McCulloch notes that, as far as colonial management of mental disease was concerned, ethnopsychiatrists were "evidence of the civic virtue of settler societies, symbolizing their ability to construct a state which mimicked the grand configurations of the metropoles"(1). It was believed that "to 'cure' a native properly [meant] to make him thoroughly a part of a social background of the colonial type" (6). New innovations in drug therapy for mental illness were used as much to cure as to encourage conformity. The director of the Zomba Asylum, for example, wrote in 1951 that "the use of sedatives and hypnotics had an excellent effect upon patients. Because they slept better, tempers improved and fighting lessened.... The inherently cheerful, sunny temper of the African reasserted itself" (5). There are ominous undertones to a faith in drugs which postpone rather than provide a cure, and, moreover, to psychiatric practices whose therapeutic goal was to reestablish a Western prescription of the African personality.

A major aim, then, of mental health care for African asylums during the early twentieth century was to segregate prison populations, or, in other words, to contain the mentally ill during their preparation to become proper citizens of the Empire. It is perhaps for this reason that hypnotics, sedatives and ECT found such a warm welcome from hospital administrations. Given the economic situation for most mental institutions in colonial Africa, fiscal constraints were an enormous barrier to providing proper care: "The colonial state," like hospitals for the mentally ill, "was never designed to incorporate or absorb the indigenous population" (1).

Ethnopsychiatry embodied and perpetuated those core concepts which gave moral justification for colonialism. However, ethnopsychiatrists were at the same time positioned to note the debilitating effects of the European presence in Africa. The realization that "Europe" could be used as an idiom for "madness" precipitated a host of ethnopsychiatric theories to explain "the African mind." Carl Jung claimed that " [Europe] had projected upon peoples still sound in their instincts an unconscious 'mental derangement'" (5). Jung may have intended to warn European psychiatrists that what they defined as mental illness in Africans was in fact a cultural construct, a stereotype.

It is significant to note that in 1955, the Zomba Asylum received its first European psychiatrist. The appointment was short-lived, either because the Asylum was suited only for treating patients as a variant form of criminal or prisoner, or due to the fact that "a belief in the value of drug treatment was supplemented 
by an increasing awareness that any attempt at 'psycho-therapy' could best be carried out by Africans themselves, in their own communities" (5). Indeed, by the 1960s, mental therapy in Africa was more oriented towards out-patient, community-centred treatment (5).

For the West Indian psychiatrist Frantz Fanon, who worked in Algeria during the 1960s, the African had been "Europeanized [and thus] ceased to exist" (7). Like Carothers, Fanon medicalized the colonial situation. However, Fanon believed that colonialism alienated the African native, at times to the point of causing somatic and mental illness. He writes that "if psychiatry is a medical technique that aims to enable man no longer to be a stranger to his environment, I owe it to myself to affirm that the Arab (Algerian), permanently an alien in his own country, lives in a state of absolute depersonalization" (8). While Fanon's views may be criticized for conflating illness with social trauma, his most important works add an important "sociogenic" dimension to ethnopsychiatric practice.

In his psychological work, Black Skin, White Masks, Fanon states explicitly that "the black man's alienation is not an individual question. Beside phylogeny [Carothers's theory] and ontogeny [Darwin's theory] stands sociogeny" (7). The concerns Fanon expresses for ethnopsychiatry are also more patient-centred, as he often describes the process of illness from an Algerian perspective. According to Fanon, "it is the racist who creates his inferior" (7). In terms of the political economy of mental health, Fanon abstracts this thesis to account for some forms of mental illness which were caused and treated in the colonial hospital setting.

In Towards the African Revolution, Fanon describes a collection of psycho-somatic complaints which he theorized were caused by the trauma of colonial rule in Algeria. This constellation of symptoms, commonly known at the time as the "North African Syndrome," is typical of Fanon's attempts to medicalize the political and economic suffering of Africans under colonialism. Briefly, the North African Syndrome was described as follows:

a series of vague complaints...[where] the patient will not follow the course of treatment recommended..... He may return weeks later with the same symptoms thereby aggravating the hospital staff (3).

Without debating the validity of this syndrome, Fanon's analysis is nonetheless useful for its description of how mental illness was treated. He writes that in the hospital "the North African enters a pre-existing framework which predetermines the kind of treatment he will receive" (3). Grounded in European-derived assumptions of African physiology and character, this medical framework was informed by the earlier "phylogenic" work of ethnopsychiatrists like Carothers.

Fanon's account of his work during the 1960's at Blida-Joinville, Algeria's largest psychiatric hospital, offers a culturally-sensitive theory of mental illness and records a further critique of western medicine: "Neither at Mathari, Blida nor Ingutsheni was allowance made for the ways in which patients or their relatives understood the causes or the experience of psychosis" (1). Natives considered mental illness a matter of foreign spirit possession and not of personal weakness. Western conceptions of mental illness, on the other hand, were complicated by cultural assumptions about the violence of Africans, which "remained part of ethnopsychiatric orthodoxy until the 1960s," if not until today. This may be due in part to the gross understaffing and general lack of mental institutions throughout the colonial era, where only the most violent patients ever received the attention of European doctors.

Reports from the Zomba Asylum show an apparent increase in mental illness in Africans in the decades surrounding the Second World War. This lends credence to Fanon's link between the colonial condition and mental illness. An annual Nyasaland public health report, written during the war years, reads that

whether it is the stress and strain of modern life, or arises out of feelings of guilt, or whether it is 
a matter of economics or improved education cannot be determined with accuracy--but undoubtedly the emergent African is paying a penalty in neuroses and anxiety states quite unknown in years gone by (1).

Compounding this increased frequency of mental illness was the unavoidable fact that colonial mental health care was largely a failure: "The asylums in Africa did not offer effective treatment; most patients were unreachable, and there was never sufficient staff to cater for anything more than their physical needs" (1). In Algeria, as in many other European colonies, most resources were directed towards opposing wars of independence waged by the native populations.

This act alone may have increased the prevalence of mental illness amongst Europeans and Algerians alike.

Social and economic conditions had an irrefutable effect on mental health in colonial Africa, and shaped the theoretical frameworks of early ethnopsychiatry. From Carothers to Fanon, there was a move from bodycentred physiological explanations to ethnopsychiatry that is rooted in broader social, historical and psychological factors. The ideological implications of this shift are such that Carothers's research was used as scientific justification for certain stereotypes of Africans, whereas Fanon's "sociogenic" theories constitute one of the most renowned polemics of the 1960s against colonialism available in medical literature.

Therefore, mental health in Africa was entrenched in the political economy of European colonization. The ethnopsychiatric theories of Carothers and Fanon demonstrate the essential images of Africans and their sicknesses which affected not just health care but many social and political interactions between European colonizers and African peoples. It has been argued that ethnopsychiatry as a field rose and fell in parallel with the history of colonial involvement in Africa, to be supplanted by the contemporary field of transcultural psychiatry. Indeed, by the 1960s many asylums for the mentally ill were relying on native forms of treatment, and Carothers's "frontal lobe" theories had grown into disrepute.

Today, the challenges of integrating western and indigenous theories of mental health are as difficult as ever, as in post-apartheid South Africa: "The racial integration of services poses challenges for culturally appropriate care... There has been uneven development in understanding indigenous healing in South Africa, a factor which may be explained partly by continuing ideological tensions" (9). Thus, the historical legacy of ethnopsychiatry demonstrates that mental health care is far from ideologically neutral, where the cultural concerns of both health care provider and receiver must be balanced carefully.

\section{REFERENCES}

1. McCulloch J. Colonial Psychiatry and "the African Mind." New York: Cambridge University Press; 1995.

2. Carothers JC. The African Mind in Health and Disease: A Study in Ethnopsychiatry. Geneva: World Health Organization; 1953.

3. McCulloch J. Black Soul White Artifact: Fanon's Clinical Psychology and Social Theory. New York: Cambridge University Press; 1983.

4. Prince R. John Colin D. Carothers (1903-1989) and African Colonial Psychiatry. Transcultural Psychiatric Research Review 33: 226-240; 1996.

5. Vaughan M. Idioms of madness: Zomba lunatic asylum, Nyasaland, in the Colonial Period. Journal of Southern African Studies 9: 218-238; 1983.

6. Fanon F. The Wretched of the Earth. Translation: C Farrington. New York: Grove Press; 1963.

7. Fanon F. Black Skin, White Masks. Translation: CL Markmann. New York: Grove Press; 1968. 
8. Bhabha H. Remembering Fanon: Self, Psyche and the Colonial Condition. In: Williams P, Chrisman L, eds. Colonial Discourse and Post-Colonial Theory: A Reader. New York: Columbia Univerisity Press;1986: 112-124.

9. Swartz L. Culture and mental health in the rainbow nation: transcultural psychiatry in a changing South Africa. Transcultural Psychiatric Research Review 33: 119-136; 1996.

\section{BIOGRAPHY}

Nicholas J. Carson received his BA in English Literature from McGill University (Montreal, Quebec, Canada) in 1996. His honors thesis in cultural studies examined American prison literature of the 1960s. He also studied post-colonial theory and medical history within McGill's Department of African Studies. Nicholas is currently a second year student in McGill University's Faculty of Medicine.

Copyright (C) 1997 by MJM 